\title{
Islet amyloid polypeptide (amylin): no evidence of an abnormal precursor sequence in 25 Type 2 (non-insulin-dependent) diabetic patients
}

\author{
M. Nishi ${ }^{1}$, G. I. Bell ${ }^{1,2,3}$ and D.F.Steiner ${ }^{1,2,3}$ \\ ${ }^{1}$ Departments of Biochemistry and Molecular Biology and ${ }^{2}$ Medicine, and ${ }^{3}$ Howard Hughes Medical Institute, \\ The University of Chicago, Chicago, Illinois, USA
}

\begin{abstract}
Summary. Islet amyloid polypeptide is the major protein component of the islet amyloid of patients with Type 2 (noninsulin-dependent) diabetes mellitus. Since the synthesis of a structurally abnormal or mutant protein may contribute to the formation of amyloid deposits, we have examined the possibility that a mutant form of islet amyloid polypeptide or its precursor contributes to the formation of islet amyloid in Type 2 diabetic patients. We have sequenced the islet amyloid polypeptide precursor coding regions of the gene of 25 patients with Type 2 diabetes. Genomic DNA fragments corresponding to exon 2 and 3 of the islet amyloid polypeptide gene were amplified from patients' peripheral blood leucocyte DNAs using the polymerase chain reaction and specific oligonucleotide primer sets, and then directly se-
\end{abstract}

quenced. The nucleotide sequences of the amplified regions of both alleles of the islet amyloid polypeptide gene of these 25 patients were identical to one another and to the sequence of an islet amyloid polypeptide allele isolated from a human fetal liver genomic library. These findings suggest that a primary structural abnormality of islet amyloid polypeptide or its precursor is unlikely to play a significant role in the formation of islet amyloid in Type 2 diabetic patients.

Key words: Islet amyloid polypeptide, Type 2 (non-insulindependent) diabetes mellitus, polymerase chain reaction, direct sequencing, maturity onset diabetes mellitus of the young (MODY), Pima Indian.
The presence of amyloid deposits is one of the most characteristic morphological features of the islets of Langerhans of patients with Type 2 (non-insulin-dependent) diabetes mellitus [1]. Amyloid deposits are also present in the islets of aged individuals although the extent of involvement is less than occurs in diabetic subjects. In addition, islet amyloid is associated with some insulinomas [2]. A major protein component of islet amyloid is islet amyloid polypeptide (IAPP) or amylin, a 37 amino acid carboxyamidated hormone-like peptide that is structurally related to the calcitonin gene-related peptides $[3,4]$. The morphological data and preliminary physiological data suggest that islet amyloid and/or IAPP may be responsible for impaired Beta cell function and peripheral insulin resistance in Type 2 diabetes [5].

The characterization of the fibrillar proteins present in the amyloid deposits associated with other disorders of localized as well as systemic amyloidosis has shown that the synthesis of a structurally abnormal or mutant protein can contribute to the formation of amyloid deposits [6]. Although the amino acid sequence of human IAPP determined directly from protein isolated from insulinomas [3] and diabetic pancreas [4] was identical to that predicted from the sequences of both cDNA [7] and genomic clones [8], it is possible that the synthesis of a variant form of the IAPP precursor contributes to the formation of islet amyloid. In order to examine this possibility and to determine the degree of sequence variation in the human IAPP gene, we have sequenced the IAPP precursor encoding regions of 25 Type 2 diabetic patients.

\section{Subjects and methods}

Twenty-five unrelated Type 2 diabetic patients were studied. These included 13 African-Americans, 10 Caucasians, one Pima Indian (individual 4011) and one affected individual from the RW Pedigree (individual 1246) - a large family with maturity-onset diabetes of the young (MODY) [9]. The diagnosis of Type 2 diabetes was made according to the recommendations of the National Diabetes Data Group.

\section{Amplification of the IAPP gene and direct sequencing}

Amplification of genomic DNA and followed by direct sequencing was carried out essentially as described by Kadowaki et al. [10]. Genomic DNA fragments corresponding to exons 2 and 3 of the 


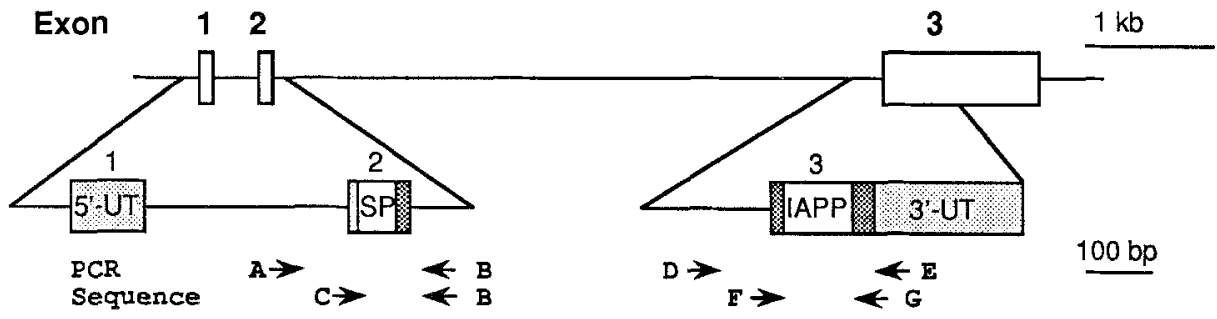

Oligonucleotide primers

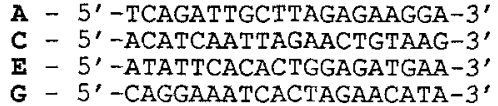

Fig. 1. Schematic representation of the human islet amyloid polypeptide (IAPP) gene. The exon-intron organization of the gene is indicated. The primers used for polymerase chain reaction (PCR) and/or DNA sequencing are noted. The arrows indicate the orientation of the primer. The abbreviations are: $5^{\prime}$ and $3^{\prime}$-UT $-5^{\prime}$ - and $3^{\prime}$ untranslated region; and $\mathrm{SP}$ - signal peptide. The shaded areas flanking IAPP are the $\mathrm{NH}_{2}$ - and $\mathrm{COOH}$-terminal propeptide segments of the IAPP precursor. The sizes of the PCR products generated using primer sets A-B and D-E are 392 and 436 basepairs (bp), respectively. The region of exon 2 whose sequence was determined included exon 2 (95 bp) and about $40 \mathrm{bp}$ of each of the flanking introns. The region of exon 3 sequenced included at least $5 \mathrm{bp}$ of intron 2 and all of the protein coding region of exon 3 (187 bp)

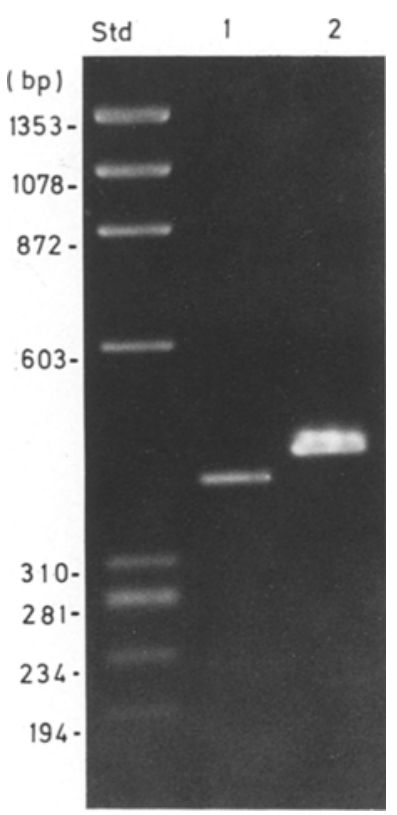

Fig. 2. Amplification of exon 2 and 3 of the human islet amyloid polypeptide gene by polymerase chain reaction (PCR). Photographs of ethidium bromide-stained agarose gels of PCR products are shown. Lane 1: exon 2, Lane 2: exon 3, Std: DNA standard (Hae III digest of $\Phi$ X174 DNA)

IAPP gene were amplified from patients' peripheral blood leucocyte DNA by the polymerase chain reaction (PCR) using specific oligonucleotide primer sets (Fig. 1). Each reaction mixture $(100 \mu \mathrm{l})$ contained $1 \mu \mathrm{g}$ of DNA, $100 \mathrm{pmol}$ of each primer and 2.5 units of Thermus aquaticus (Taq) DNA polymerase in a solution of $50 \mathrm{mmol} / \mathrm{l}$ $\mathrm{KCl}, 10 \mathrm{mmol} / \mathrm{Tris}-\mathrm{HCl}(\mathrm{pH} 8.3), 1.5 \mathrm{mmol} / \mathrm{l} \mathrm{MgCl}, 0.001 \%$ gelatin and $200 \mu \mathrm{mol} / \mathrm{l}$ of each deoxyribonucleotide triphosphate. The PCR was carried out in the DNA Thermal Cycler (Perkin-Elmer Cetus Co., Norwalk, Conn., USA) through 30 cycles: denaturation for $1 \mathrm{~min}$ at $94^{\circ} \mathrm{C}$; annealing for $2 \mathrm{~min}$ at $55^{\circ} \mathrm{C}$; and extension for $2 \mathrm{~min}$ at $72^{\circ} \mathrm{C}$. Aliquots $(0.5 \sim 1.0 \mu \mathrm{l})$ of the first PCR products were then amplified through 25 cycles using only one primer to synthesize single stranded DNA templates for DNA sequencing. Other conditions of the second PCR were the same as described above. The products of the second PCR reaction were filtered through a Centricon 100 membrane (Amicon, Beverly, Mass., USA), dried in a Speed Vac concentrator (Savant, Hicksville, NY, USA) and dissolved in $16 \mu$ l of water. ${ }^{32} \mathrm{P}$-labelled sequencing primers were prepared by phosphorylation with T4 polynucleotide kinase (New England Biolabs, Beverly, Mass., USA) and $\left[\gamma^{32} \mathrm{P}\right]$ ATP (Dupont, Wilmington, Delaware, USA). The ${ }^{32}$ P-labelled oligonucleotides were purified by Sephadex G-25 Quick Spin Column (Boehringer-Mannheim, Indianapolis, Ind., USA) dried in the Speed Vac concentrator and dissolved in $30 \mu \mathrm{l}$ of water. Amplified single stranded DNA $(5 \mu \mathrm{l})$ was mixed with 1-3 $\mu \mathrm{l}$ (3-5 pmol) of ${ }^{32} \mathrm{P}$-labelled oligonucleotide primer in $50 \mathrm{mmol} / /$ Tris- $\mathrm{HCl}$ ( $\mathrm{pH} 8.3$ ), $8 \mathrm{mmol} / / \mathrm{MgCl}_{2}, 30 \mathrm{mmol} / \mathrm{l}$ $\mathrm{KCl}$ and $10 \mathrm{mmol} / \mathrm{l}$ dithiothreitol. After heating for $10 \mathrm{~min}$ at $94^{\circ} \mathrm{C}$, $2.5 \mu \mathrm{l}$ of the mixture was added to each of four tubes followed by $2 \mu \mathrm{I}$ of the appropriate dideoxy terminator and sequenase mix $[80 \mu \mathrm{mol} / 1$ each of four deoxyribonucleotide triphosphate and 1.2 units of Sequenase (United States Biochemical Co., Cleveland, Ohio, USA)]. After incubation at $50^{\circ} \mathrm{C}$ for $40 \mathrm{~min}$ the reaction was terminated by adding $3 \mu \mathrm{l}$ of stop solution ( $95 \%$ formamide, $20 \mathrm{mmol} / 1$ EDTA, $0.05 \%$ bromophenol blue and $0.05 \%$ xylene cyanol FF). The samples were analysed by electrophoresis through a $5 \%$ polyacrylamide and $8 \mathrm{~mol} / \mathrm{l}$ urea gel. After electrophoresis, the gel was dried and autoradiographed.

\section{Results and discussion}

Using the sequence of the human IAPP gene [8] as a guide, we selected primers that allowed the protein coding region of exons 2 and 3 of human IAPP gene to be amplified by PCR (Fig.1,2). The analysis of the PCR products by gel electrophoresis indicated that little non-specific priming occurred (Fig. 2). The sequences of the amplified region corresponding to both alleles of the IAPP gene of 25 Type 2 diabetic patients were identical to one another and to the sequence of the cloned gene. Thus, it is unlikely that a primary structural abnormality of IAPP or its precursor plays a significant role in the formation of islet amyloid. Since the sequences of 50 alleles of the IAPP gene were determined, the frequency of mutations in IAPP or its precursor in Type 2 diabetes patients is likely to be less than $2 \%$. These data suggest that the high incidence of islet amyloid in Type 2 diabetes may result from the increased expression and/or abnormal production, process- 
ing or secretion of IAPP or its precursor rather than the synthesis of a structurally abnormal protein. In this regard, mutations in the promoter region of the IAPP gene of diabetic patients could result in abnormal regulation of its expression thereby leading to excessive IAPP secretion.

Acknowledgements. We thank Dr. C.Bogardus for providing the Pima Indian DNA sample, Mr. P. Gardner for synthesis of oligonucleotides and Ms. F. Rozenfeld for her expert assistance in the preparation of the manuscript. Work from our laboratories has been supported by NIH grants DK 13914 and DK 20595 and the Howard Hughes Medical Institute.

\section{References}

1. Ehrlich JC, Ratner IM (1961) Amyloidosis of the islets of Langerhans: a restudy of islet hyalin in diabetic and nondiabetic individuals. Am J Pathol 38: 49-59

2. Westermark P, Grimelius L, Polak JM, Larsson L-I, Noorden S van, Wilander E, Pearse AGE (1977) Amyloid in polypeptide hormone-producing tumors. Lab Invest 37: 212-215

3. Westermark P, Wernstedt C, Wilander E, Hayden DW, O'Brien TD, Johnson KH (1987) Amyloid fibrils in human insulinoma and islets of Langerhans of the diabetic cat are derived from a neuropeptide-like protein also present in normal islets. Proc Natl Acad Sci USA 84: 3881-3885

4. Clark A, Lewis CE, Willis AC, Cooper GJS, Morris JF, Reid KBM, Turner RC (1987) Islet amyloid formed from diabetes-as- sociated peptide may be pathogenic in type-2 diabetes. Lancet II: 231-234

5. Cooper GJS, Leighton B, Dimitriadis GD, Parry-Billings M, Kowalchuk M, Howland K, Rothbard BJ, Willis AC, Reid KBM (1988) Amylin found in amyloid deposits in human type 2 diabetes mellitus may be a hormone that regulates glycogen metabolism in skeletal muscle. Proc Natl Acad Sci USA 85: 77637766

6. Pepys MB (1988) Amyloidosis: some recent developments. Q J Med 76: 283-298

7. Sanke T, Bell GI, Sample C, Rubenstein AH, Steiner DF (1988) An islet amyloid peptide is derived from an 89-amino acid precursor by proteolytic processing. J Biol Chem 263: 17243-17246

8. Nishi M, Sanke T, Seino S, Eddy RL, Fan Y-S, Byers MG, Shows TB, Bell GI, Steiner DF (1989) Human islet amyloid polypeptide gene: complete nucleotide sequence, chromosomal localization, and evolutionary history. Mol Endocrinol 3: 1775-1781

9. Fajans SS (1989) Maturity-onset diabetes of the young (MODY). Diabetes Metab Rev 5: 579-606

10. Kadowaki T, Kadowaki H, Taylor SI (1990) A nonsense mutation causing decreased levels of insulin receptor mRNA: detection by a simplified technique for direct sequencing of genomic DNA amplified by the polymerase chain reaction. Proc Natl Acad Sci USA 87: 658-662

Received: 8 May 1990

Dr.D.F.Steiner

Department of Biochemistry and Molecular Biology

Howard Hughes Medical Institute

5841 S. Maryland Avenue, N 216 (Box 23)

Chicago IL 60637

USA 